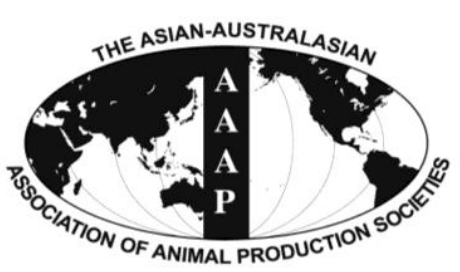

Open Access

Asian Australas. J. Anim. Sci.

Vol. 27, No. 2 : 194-200 February 2014

http://dx.doi.org/10.5713/ajas.2013.13446

www.ajas.info

pISSN 1011-2367 elSSN 1976-5517

\title{
Assessment of the Nutritive Value of Whole Corn Stover and Its Morphological Fractions
}

\author{
H. Y. Li ${ }^{1,2}$, L. Xu ${ }^{1}{ }^{*}$, W. J. Liu ${ }^{1}$, M. Q. Fang ${ }^{1}$, and N. Wang ${ }^{1}$ \\ ${ }^{1}$ Northeast Agricultural University, 59 Mucai St, Xiangfang District, Harbin 150030, China
}

\begin{abstract}
This study investigated the chemical composition and ruminal degradability of corn stover in three maize-planting regions in Qiqihaer, Heilongjiang Province, China. The whole stover was separated into seven morphological fractions, i.e., leaf blade, leaf sheath, stem rind, stem pith, stem node, ear husk, and corn tassel. The assessment of nutritive value of corn stover and its fractions was performed based on laboratory assays of the morphological proportions, chemical composition, and in situ degradability of dry matter (DM), neutral detergent fiber (NDF), and acid detergent fiber (ADF). The chemical composition of corn stover was significantly different from plant top to bottom $(\mathrm{p}<0.05)$. Among the whole corn stover and seven morphological fractions, leaf blade had the highest crude protein $(\mathrm{CP})$ content and the lowest NDF and ADF contents $(\mathrm{p}<0.05)$, whereas stem rind had the lowest CP content and the highest ADF and acid detergent lignin (ADL) contents $(\mathrm{p}<0.05)$. Ear husk had significantly higher NDF content and relatively lower ADL content than other corn stover fractions. Overall, the effective degradability of DM, NDF, and ADF in rumen was the highest in leaf blade and stem pith, followed by ear husk. The results indicate that leaf blade, ear husk, and stem pith potentially have higher nutritive values than the other fractions of corn stover. This study provides reference data for high-efficiency use of corn stover in feeding ruminants. (Key Words: Whole Corn Stover, Morphological Fraction, Chemical Composition, In situ Degradability, Qiqihaer)
\end{abstract}

\section{INTRODUCTION}

Corn stover is one of the main crop straws characterized by multi-source, wide distribution, high abundance, low cost, less competing usage, and great potential for development and utilization. Presently, global annual production of straw is $\sim 2.9$ billion ton, with corn stover contributing $35 \%$ to the total. In China, the production of corn stover is $\sim 0.3$ billion ton, accounting for $56.6 \%$ of the national annual production of straw (including the straw of rice, wheat, corn, beans, tubers, oil-bearing crops, cotton, hemp, sugar crops, and other crops) (Zeng et al., 2007).

With an increasing number of poultry and livestock, their competition for food with humans has led to wide concern. Reasonable development and utilization of straw as feed source can provide a material basis for herbivorous

\footnotetext{
* Corresponding Author: L. Xu. Tel: +86-451-55190736, Fax: +86-451-55190840, E-mail: xuli_19621991@163.com

${ }^{2}$ Animal Science Institute of Heilongjiang Province, 2 Heyi St, Longsha District, Qiqihaer 161005, China.

Submitted Jul. 24, 2013; Accepted Sept. 16, 2013; Revised Oct. 9, 2013
}

livestock such as cows and sheep. To date, a large number of countries, especially developing countries have used straw as feed for their herbivorous livestock. However, the application of straw as feed is largely limited due to the compositional characteristics such as abundant fiber content, low protein level, and low energy.

Previously, a machine for separation of sweet sorghum pith and rind was designed to achieve high-efficiency use of the stalk (Crandell and Worley, 1988). In recent years, the mechanical properties of corn stover stalks have been investigated (Lee et al., 2006; Grundas and Skubisz, 2008), and a device for separation of corn stover rind and pith has been developed in China (Liu and Wang, 2011). It is thought that by separating different parts of the stalk, corn stover can be used more efficiently for different purposes. For example, the rind of corn stover has been used as highquality fiber to produce glazed paper, high strength corrugated paper, and packaging board, as well as plywood for construction (Zhou et al., 2011), whereas the separated leaf and pith tissues with less fiber content can be used as feed for ruminants. In this way, it is possible to improve the 
effectiveness of stalk utilization, increase associated income, and benefit the environment, thereby creating tremendous social and economic values.

For better utilization of straw as feed by ruminants, indepth research needs to be conducted on the physicochemical composition of straw and the anatomy of tissues related to rumen fermentation, as well as other inherent factors. A large body of work shows that the chemical composition and nutritive value of plant tissues vary in different straw fractions of rice and wheat (Sannasgala and Jayasuriya, 1987; Shand et al., 1988; Tan et al., 1995; Vadiveloo, 2000; Wang et al., 2006). However, few reports are available on the major chemical composition of corn stover (Ahmed and Zhu, 2006; Hess et al., 2002), and no study has assessed the nutritive value of different fractions of corn stover for feeding ruminants.

In the present study, we investigated the chemical composition, ruminal degradability, and effective degradability of the whole plant and different fractions of corn stover, and further explored the dynamic variation trend in their nutritive value. The results will provide supporting data for making full use of corn stover as a feed source of ruminants.

\section{MATERIALS AND METHODS}

\section{Sample collection}

In mid-September 2011, 30 corn stover samples (waxy maize) were collected from 3 maize-planting regions $(\mathrm{n}=$ 10 per region) in Qiqihaer, Heilongjiang Province, northeastern China. The corn stover was dried in good preservation without peeling. Leaf blade, leaf sheath, stem rind, stem pith, stem node, ear husk, and tassel were manually striped from the whole corn stover. Stem rind and stem pith were obtained by stripping from the internode of cornstalk, and stem node was obtained by snipping the line of the joint of culm within $0.8 \mathrm{~cm}$. The corn stover samples were dried at $60^{\circ} \mathrm{C}$ to constant weight and then ground to powder before use.

\section{Chemical compositional analyses}

The chemical composition of whole corn stover and its morphological fractions were assayed as follows: Total dry matter (DM) and organic matter (OM) contents determined by oven drying at $105^{\circ} \mathrm{C}$ overnight and loss-on-ignition in a muffle furnace at $525^{\circ} \mathrm{C}$ for $8 \mathrm{~h}$, respectively; the nitrogen $(\mathrm{N})$, calcium $(\mathrm{Ca})$ and phosphorus $(\mathrm{P})$ contents measured following standard methods (AOAC, 1990); the crude protein $(\mathrm{CP})$ content calculated as $\mathrm{N} \times 6.25$; the ether extract (EE) determined by Soxtec extraction with petroleum ether; the neutral detergent fiber (NDF), acid detergent fiber (ADF), and acid detergent lignin (ADL) determined following the procedures outlined by Goering and Van
Soest (1970) with modifications described by Van Soest et al. (1991)

\section{In situ rumen degradation}

In situ rumen degradation of whole corn stover and its morphological fractions were evaluated in 3 ruminally cannulated Chinese - Holstein dry cows $(\sim 550 \mathrm{~kg} \mathrm{BW})$. The cows were housed in individual tie stalls bedded with rubber on a plank bed and fed diets containing leymus chinensis (28\%), corn silage (42\%), and concentrate mixture $(30 \%)$ at maintenance levels. The dried and ground corn stover samples were weighed into dacron bags $(12 \times 9$ $\mathrm{cm}$; 40 to 45 micron pore size) and incubated in the rumen of cows for different periods, i.e., $0 \mathrm{~h}, 4 \mathrm{~h}, 8 \mathrm{~h}, 12 \mathrm{~h}, 24 \mathrm{~h}$, $48 \mathrm{~h}$, and $72 \mathrm{~h}$.

After incubation, the bags were removed from the rumen, washed in cold water till the rinse solution became clear, and then dried at $60^{\circ} \mathrm{C}$ for $48 \mathrm{~h}$ as described by Karsli and Russell (2002). The rumen degradation kinetics of DM, NDF, and ADF were calculated using a nonlinear model proposed by Ørskov and McDonald (1979) as follows:

$$
y=a+b\left(1-\mathrm{e}^{-c t}\right)
$$

where,

$y=$ Ruminal degradability of the response variables at time $t$

$t=$ Incubation time $(\mathrm{h})$

$a=$ Highly soluble and readily degradable fraction of corn stover (\%)

$b=$ Insoluble and slowly degradable fraction of corn stover $(\%)$

$c=$ Rate constant of degradation $\left(\% \mathrm{~h}^{-1}\right)$

$\mathrm{e}=2.7182$ (The base for natural logarithm)

After the abovementioned parameters were determined, the effective degradability of DM, NDF, and ADF in whole plant, leaf blade, leaf sheath, stem rind, stem pith, stem node, ear husk, and tassel of corn stover were calculated using the equation described by Ørskov and McDonald (1979) as follows:

$$
\mathrm{ED}=a+(b \times c) /(c+\mathrm{k})
$$

where,

$\mathrm{ED}=$ Effective degradability of the response variables

$a=$ Highly soluble and readily degradable fraction of corn stover (\%)

$b=$ Insoluble and slowly degradable fraction of corn stover $(\%)$

$c=$ Rate constant of degradation $\left(\% \mathrm{~h}^{-1}\right)$

$\mathrm{k}=$ Rate constant of passage $\left(\% \mathrm{~h}^{-1}\right)$

In the calculation of effective degradability, the rate constant of passage was assumed to be 0.025 per hour 
Table 1. Chemical composition of whole corn stover and different morphological fractions (\%, air-dry basis)

\begin{tabular}{lcccccccccc}
\hline Nutrient & Tassel & Leaf blade & Leaf sheath & Stem rind & Stem pith & Stem node & Ear husk & Whole plant & SEM & p-value \\
\hline $\mathrm{DM}$ & 92.96 & 92.88 & 92.45 & 93.30 & 93.26 & 92.20 & 93.38 & 93.38 & 0.08 & 0.43 \\
$\mathrm{CP}$ & $6.60^{\mathrm{b}}$ & $9.95^{\mathrm{a}}$ & $4.25^{\mathrm{c}}$ & $1.94^{\mathrm{e}}$ & $3.33^{\mathrm{d}}$ & $4.20^{\mathrm{c}}$ & $2.26^{\mathrm{e}}$ & $4.05^{\mathrm{c}}$ & 0.23 & $<0.01$ \\
$\mathrm{EE}$ & $1.40^{\mathrm{a}}$ & $1.49^{\mathrm{a}}$ & $1.02^{\mathrm{bcd}}$ & $0.60^{\mathrm{e}}$ & $1.22^{\mathrm{abc}}$ & $0.92^{\mathrm{cde}}$ & $0.87^{\mathrm{de}}$ & $1.31^{\mathrm{ab}}$ & 0.13 & 0.02 \\
$\mathrm{OM}$ & $93.05^{\mathrm{b}}$ & $92.46^{\mathrm{a}}$ & $93.78^{\mathrm{c}}$ & $97.27^{\mathrm{g}}$ & $95.20^{\mathrm{d}}$ & $95.58^{\mathrm{e}}$ & $96.92^{\mathrm{f}}$ & $95.16^{\mathrm{d}}$ & 0.64 & $<0.01$ \\
$\mathrm{NDF}$ & $71.39^{\mathrm{c}}$ & $62.28^{\mathrm{e}}$ & $74.81^{\mathrm{b}}$ & $71.06^{\mathrm{c}}$ & $70.49^{\mathrm{d}}$ & $72.33^{\mathrm{c}}$ & $82.69^{\mathrm{a}}$ & $71.93^{\mathrm{c}}$ & 0.62 & $<0.01$ \\
$\mathrm{ADF}$ & $37.80^{\mathrm{d}}$ & $31.12^{\mathrm{e}}$ & $39.01^{\mathrm{c}}$ & $47.59^{\mathrm{a}}$ & $39.05^{\mathrm{c}}$ & $39.24^{\mathrm{c}}$ & $43.34^{\mathrm{b}}$ & $41.36^{\mathrm{c}}$ & 0.39 & $<0.01$ \\
$\mathrm{ADL}$ & $5.78^{\mathrm{cd}}$ & $4.43^{\mathrm{ef}}$ & $5.72^{\mathrm{de}}$ & $8.32^{\mathrm{a}}$ & $4.33^{\mathrm{f}}$ & $6.80^{\mathrm{b}}$ & $3.60^{\mathrm{f}}$ & $6.26^{\mathrm{b}}$ & 0.34 & $<0.01$ \\
$\mathrm{Ca}$ & $0.61^{\mathrm{b}}$ & $1.01^{\mathrm{a}}$ & $0.53^{\mathrm{c}}$ & $0.45^{\mathrm{de}}$ & $0.41^{\mathrm{e}}$ & $0.47^{\mathrm{df}}$ & $0.21^{\mathrm{g}}$ & $0.40^{\mathrm{f}}$ & 0.02 & $<0.01$ \\
$\mathrm{P}$ & $0.07^{\mathrm{b}}$ & $0.11^{\mathrm{a}}$ & $0.06^{\mathrm{bc}}$ & $0.03^{\mathrm{c}}$ & $0.03^{\mathrm{c}}$ & $0.05^{\mathrm{bc}}$ & $0.07^{\mathrm{bc}}$ & $0.05^{\mathrm{bc}}$ & 0.01 & 0.006 \\
\hline
\end{tabular}

${ }^{\mathrm{a}-\mathrm{g}}$ Means in the same row with different superscript letters are different at $\mathrm{p}<0.05$.

$\mathrm{DM}=$ Dry matter, $\mathrm{CP}=$ Crude protein, $\mathrm{EE}=$ Ether extract; $\mathrm{OM}=$ Organic matter; $\mathrm{NDF}=$ Neutral detergent fiber, $\mathrm{ADF}=\mathrm{Acid}$ detergent fiber, $\mathrm{ADL}=$ Acid detergent lignin, $\mathrm{P}=$ Phosphorus, $\mathrm{Ca}=$ Calcium.

$\mathrm{SEM}=$ Standard error of mean

according to Feed Criteria of Dairy Cows in China (Han, 2007).

\section{Statistical analyses}

All data are subjected to one-way ANOVA by using the GLM procedure in SAS (Ver9.0 for Windows). If significant differences $(\mathrm{p}<0.05)$ were detected in treatment means by ANOVA, Duncan's multiple rang test was further applied to mean pairs.

\section{RESULTS}

\section{Nutrient composition}

The nutrient composition of corn stover substantially varied among different morphological fractions from the whole plant (Table 1). For example, leaf blade had the highest $\mathrm{CP}$ content $(9.95 \%)$ and the lowest NDF and ADF contents $(62.28 \%$ and $31.12 \%$, respectively) $(\mathrm{p}<0.05)$, whereas stem rind had the lowest CP content (1.94\%) and the highest ADF and ADL contents $(47.59 \%$ and $8.32 \%$,

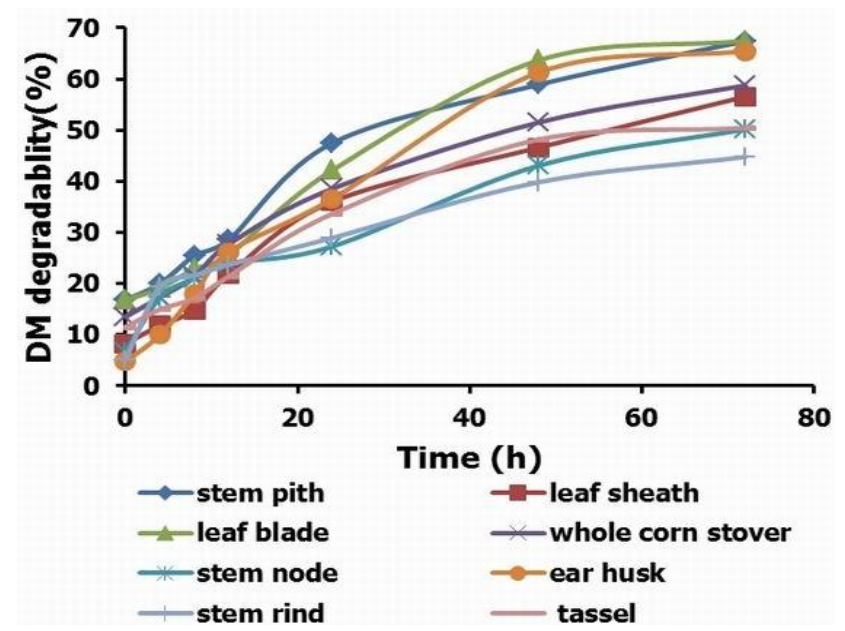

Figure 1. Dry matter degradability of whole corn stover and different morphological fractions during rumen incubation for different periods in dry cows. respectively) $(\mathrm{p}<0.05)$. Ear husk had significantly higher NDF content $(82.69 \%)$ and relatively lower ADL content (3.60\%) compared to other corn stover fractions.

Leaf blade had the highest $\mathrm{Ca}$ and $\mathrm{P}$ contents $(1.01 \%$ and $0.11 \%$, respectively), whereas ear husks had the lowest Ca content $(0.21 \%)$ and stem pith (and rind) had the lowest $\mathrm{P}$ content $(0.03 \%)$. The OM content of leaf blade was $92.46 \%$, significantly lower than that of other fractions, i.e., $93.05 \%$ to $93.78 \%$ in tassel and leaf sheath; $95.16 \%$ to $95.58 \%$ in whole plant, stem pith, and stem node; and $96.92 \%$ to $97.27 \%$ in ear husk and stem rind. There were no significant differences in the DM content the whole plant and 7 morphological fractions of corn stover $(p>0.05)$ (Table 1).

\section{Ruminal disappearance rate}

The ruminal disappearance rate of major nutrient contents of corn stover fractions positively increased with the incubation time (Figures 1 to 3). Overall, the DM, NDF and $\mathrm{ADF}$ of corn stover fractions disappeared at low rates

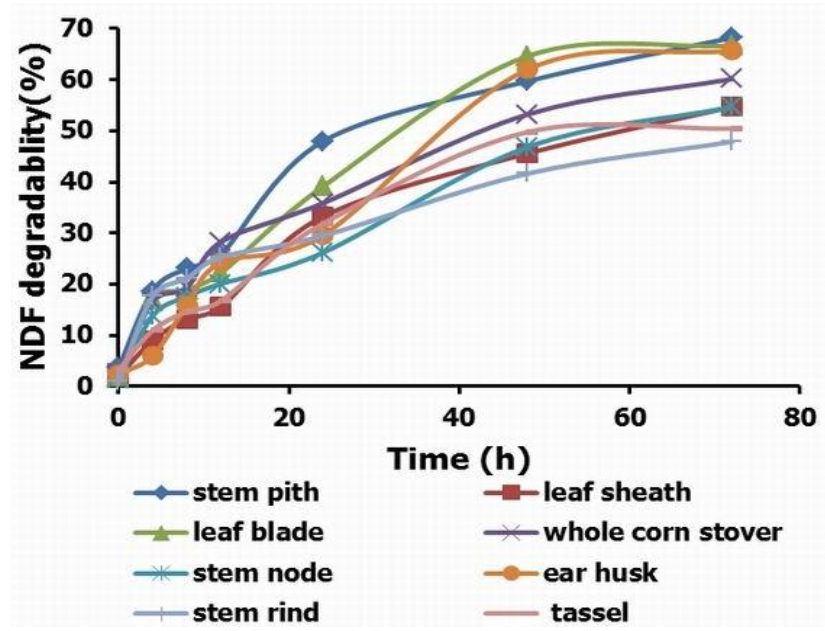

Figure 2. Neutral detergent fiber degradability of whole corn stover and different morphological fractions during rumen incubation for different periods in dry cows. 


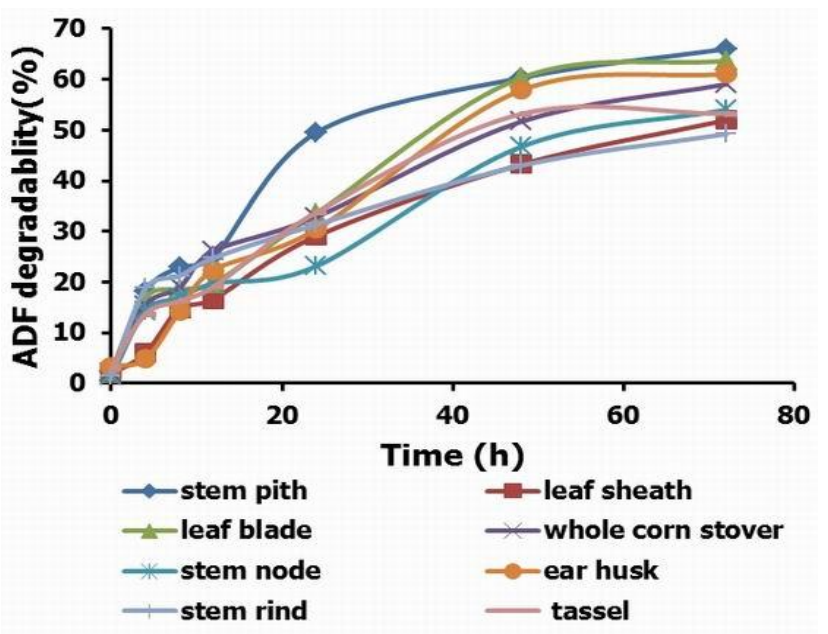

Figure 3. Acid detergent fiber degradability of whole corn stover and different morphological fractions during rumen incubation for different periods in dry cows.

within the first $12 \mathrm{~h}$ in rumen, as indicated by the small slope of the variation curve. After 12-h incubation, the ruminal disappearance rates of DM, NDF, and ADF of corn stover fractions obviously increased.

During rumen incubation, there were significant differences in the ruminal disappearance rate of major nutrient contents among the whole corn stover and different fractions (Tables 2 to 4 ) ( $<<0.001)$. For example, the ruminal disappearance rates of DM, NDF, and $\mathrm{ADF}$ of leaf blade, ear husk, and stem pith were significantly higher than those of other corn stover fractions at $48 \mathrm{~h}$ and $72 \mathrm{~h}$ (leaf blade>ear husk>stem pith). The ruminal disappearance rates of NDF of the abovementioned 3 fractions at $48 \mathrm{~h}$ followed the same order: leaf blade>ear husk>stem pith, while that of ADF decreased in the following order: leaf blade >stem pith $>$ ear husk. The corresponding ruminal disappearance rates of NDF and ADF at $72 \mathrm{~h}$ both decreased in the following order: stem pith>leaf blade>ear husk. Stem rind had the lowest ruminal disappearance rates of DM, NDF, and ADF at both $48 \mathrm{~h}$ and $72 \mathrm{~h}$ compared to other morphological fractions.

\section{Effective degradability rate}

The effective degradability of major nutrient contents showed different variation trends among the whole corn stover and different fractions (Table 5). Among different corn stover fractions, the effective degradability of DM in rumen was the highest in leaf blade and stem pith, followed by ear husk and whole plant. For the remaining fractions, the effective degradability of DM in rumen followed the order of leaf sheath $>$ corn tassel $>$ stem node $>$ stem rind $(\mathrm{p}<0.001)$.

The NDF of corn stover fractions was similar to that of DM, the effective degradability of NDF in rumen was the highest in stem pith and leaf blade, followed by ear husk and whole plant. For other fractions, the effective degradability of NDF in rumen followed the order of stem node $>$ leaf sheath $>$ corn tassel $>$ stem rind $(p<0.001)$.

The ADF of corn stover fractions was similar to that of DM and NDF, the effective degradability of ADF was the highest in stem pith and leaf blade, followed by whole plant and ear husk. For the remaining fractions, the effective degradability of ADF varied in the following order: corn tassel $>$ stem rind $>$ stem node $>$ leaf sheath $(p<0.001)$.

\section{DISCUSSION}

\section{Nutrient distribution of different morphological fractions of corn stover}

In this study, the results of chemical analysis showed that the nutrient composition of corn stover fractions and whole plant had large differences (Table 1). This is understandable as different plant fractions feature various cell morphologies and thus play various functions with different nutritive values. The CP content occurred at the highest level in leaf blade and tended to decrease from plant top to bottom (Table 1). Such variation in the CP content of corn stover could be attributed to the transition from older

Table 2. Ruminal disappearance rate (\%) of DM from whole corn stover and different morphological fractions

\begin{tabular}{lccccccc}
\hline \multirow{2}{*}{ Fraction } & \multicolumn{6}{c}{ Ruminal disappearance rate of dry matter at different time points (h) } \\
\cline { 2 - 7 } & 0 & 4 & 8 & 12 & 24 & 48 & 72 \\
\hline Leaf sheath & $8.23 \pm 0.37^{\mathrm{d}}$ & $11.87 \pm 0.27^{\mathrm{d}}$ & $14.82 \pm 0.29^{\mathrm{d}}$ & $21.83 \pm 2.07^{\mathrm{cd}}$ & $36.04 \pm 1.03^{\mathrm{cd}}$ & $46.62 \pm 1.01^{\mathrm{d}}$ & $56.59 \pm 2.12^{\mathrm{b}}$ \\
Leaf blade & $16.79 \pm 0.55^{\mathrm{a}}$ & $19.13 \pm 0.30^{\mathrm{a}}$ & $22.88 \pm 1.21^{\mathrm{b}}$ & $25.65 \pm 0.31^{\mathrm{abcd}}$ & $42.15 \pm 1.04^{\mathrm{b}}$ & $63.67 \pm 1.37^{\mathrm{a}}$ & $67.46 \pm 0.70^{\mathrm{a}}$ \\
Stem pith & $16.83 \pm 0.70^{\mathrm{a}}$ & $20.01 \pm 0.43^{\mathrm{a}}$ & $25.48 \pm 1.01^{\mathrm{a}}$ & $28.57 \pm 1.49^{\mathrm{a}}$ & $47.48 \pm 0.42^{\mathrm{a}}$ & $58.92 \pm 0.84^{\mathrm{b}}$ & $67.42 \pm 2.49^{\mathrm{a}}$ \\
Stem node & $6.70 \pm 0.24^{\mathrm{e}}$ & $17.28 \pm 0.19^{\mathrm{e}}$ & $21.05 \pm 0.22^{\mathrm{b}}$ & $24.00 \pm 0.28^{\mathrm{bcd}}$ & $27.27 \pm 0.23^{\mathrm{e}}$ & $43.09^{\mathrm{e}} \pm 1.40^{\mathrm{e}}$ & $50.18 \pm 1.13^{\mathrm{c}}$ \\
Stem rind & $5.16 \pm 0.17^{\mathrm{f}}$ & $19.32 \pm 0.04^{\mathrm{a}}$ & $21.62 \pm 0.51^{\mathrm{b}}$ & $23.72 \pm 1.04^{\mathrm{bcd}}$ & $28.96 \pm 0.79^{\mathrm{e}}$ & $39.86 \pm 0.84^{\mathrm{e}}$ & $44.78 \pm 1.08^{\mathrm{d}}$ \\
Ear husk & $4.75 \pm 0.21^{\mathrm{f}}$ & $9.98 \pm 0.25^{\mathrm{e}}$ & $17.97 \pm 0.60^{\mathrm{c}}$ & $26.24 \pm 1.65^{\mathrm{abc}}$ & $36.58 \pm 1.17^{\mathrm{c}}$ & $61.30 \pm 0.60^{\mathrm{ab}}$ & $65.45 \pm 1.44^{\mathrm{a}}$ \\
Tassel & $11.52 \pm 0.29^{\mathrm{c}}$ & $14.97 \pm 0.17^{\mathrm{c}}$ & $17.18 \pm 0.04^{\mathrm{c}}$ & $21.43 \pm 0.95^{\mathrm{cd}}$ & $33.64 \pm 2.15^{\mathrm{d}}$ & $48.18 \pm 1.38^{\mathrm{cd}}$ & $50.44 \pm 2.82^{\mathrm{c}}$ \\
Whole plant & $13.51 \pm 0.28^{\mathrm{b}}$ & $17.33 \pm 0.23^{\mathrm{b}}$ & $21.36 \pm 0.27^{\mathrm{b}}$ & $27.74 \pm 0.44^{\mathrm{ab}}$ & $38.54 \pm 1.23^{\mathrm{c}}$ & $51.53 \pm 1.39^{\mathrm{c}}$ & $58.78 \pm 0.72^{\mathrm{b}}$ \\
p-value & $<0.001$ & $<0.001$ & $<0.001$ & $<0.001$ & $<0.001$ & $<0.001$ & $<0.001$ \\
SEM & 0.97 & 0.63 & 0.68 & 0.60 & 1.46 & 1.62 & 1.71
\end{tabular}

${ }^{\mathrm{a}-\mathrm{f}}$ Means in the same column with different superscript letters are significantly different at $\mathrm{p}<0.05$; SEM $=$ Standard error of mean. 
Table 3. Ruminal disappearance rate (\%) of NDF from whole corn stover and different morphological fractions

\begin{tabular}{llcccccc}
\hline \multirow{2}{*}{ Fraction } & \multicolumn{6}{c}{ Ruminal disappearance rate neutral detergent fiber at different time points (h) } \\
\cline { 2 - 8 } & \multicolumn{1}{c}{0} & 4 & 8 & 12 & 24 & 48 & 72 \\
\hline Leaf sheath & $1.94 \pm 0.51^{\mathrm{bcd}}$ & $9.01 \pm 0.39^{\mathrm{e}}$ & $13.17 \pm 0.99^{\mathrm{e}}$ & $15.57 \pm 1.22^{\mathrm{e}}$ & $33.25 \pm 1.42^{\mathrm{cd}}$ & $45.58 \pm 1.24^{\mathrm{e}}$ & $54.73 \pm 1.89^{\mathrm{c}}$ \\
Leaf blade & $2.01 \pm 0.40^{\mathrm{bcd}}$ & $17.05 \pm 0.28^{\mathrm{b}}$ & $18.94 \pm 1.40^{\mathrm{bc}}$ & $22.20 \pm 1.72^{\mathrm{cd}}$ & $39.13 \pm 1.36^{\mathrm{b}}$ & $64.64 \pm 1.96^{\mathrm{a}}$ & $66.69 \pm 1.01^{\mathrm{a}}$ \\
Stem pith & $3.68 \pm 0.37^{\mathrm{a}}$ & $18.71 \pm 0.55^{\mathrm{a}}$ & $23.10 \pm 0.71^{\mathrm{a}}$ & $25.82 \pm 1.35^{\mathrm{ab}}$ & $47.97 \pm 0.58^{\mathrm{a}}$ & $59.74 \pm 0.75^{\mathrm{b}}$ & $68.23 \pm 0.62^{\mathrm{a}}$ \\
Stem node & $1.42 \pm 0.27^{\mathrm{cd}}$ & $13.82 \pm 0.54^{\mathrm{c}}$ & $17.58 \pm 0.10^{\mathrm{cd}}$ & $20.08 \pm 0.43^{\mathrm{d}}$ & $26.19 \pm 1.09^{\mathrm{e}}$ & $46.85 \pm 1.36^{\mathrm{de}}$ & $54.68 \pm 1.37^{\mathrm{c}}$ \\
Stem rind & $1.04 \pm 0.38^{\mathrm{d}}$ & $17.60 \pm 0.79^{\mathrm{ab}}$ & $21.13 \pm 1.74^{\mathrm{ab}}$ & $25.32 \pm 0.43^{\mathrm{abc}}$ & $29.50 \pm 0.92^{\mathrm{de}}$ & $41.65 \pm 0.55^{\mathrm{f}}$ & $47.89 \pm 1.03^{\mathrm{d}}$ \\
Ear husk & $2.39 \pm 0.36^{\mathrm{abcd}}$ & $5.98 \pm 0.22^{\mathrm{f}}$ & $15.84 \pm 0.32^{\mathrm{de}}$ & $24.29 \pm 1.88^{\mathrm{bc}}$ & $29.61 \pm 0.66^{\mathrm{de}}$ & $62.03 \pm 0.55^{\mathrm{ab}}$ & $65.68 \pm 1.22^{\mathrm{a}}$ \\
Tassel & $3.26 \pm 0.28^{\mathrm{ab}}$ & $10.96 \pm 0.45^{\mathrm{d}}$ & $14.64 \pm 1.26^{\mathrm{e}}$ & $16.72 \pm 0.93^{\mathrm{e}}$ & $31.88 \pm 1.92^{\mathrm{cd}}$ & $49.78 \pm 0.31^{\mathrm{d}}$ & $50.46 \pm 0.68^{\mathrm{d}}$ \\
Whole plant & $2.64 \pm 0.44^{\mathrm{abc}}$ & $16.61 \pm 0.29^{\mathrm{b}}$ & $19.32 \pm 0.36^{\mathrm{bc}}$ & $28.26 \pm 0.90^{\mathrm{a}}$ & $35.87 \pm 1.75^{\mathrm{bc}}$ & $53.24 \pm 0.73^{\mathrm{c}}$ & $60.16 \pm 0.68^{\mathrm{b}}$ \\
p-value & 0.003 & $<0.001$ & $<0.001$ & $<0.001$ & $<0.001$ & $<0.001$ & $<0.001$ \\
SEM & 2.11 & 0.92 & 0.73 & 1.01 & 1.36 & 1.63 & 1.60
\end{tabular}

${ }^{\mathrm{a}-\mathrm{e}}$ Means in the same column with different superscript letters are significantly different at $\mathrm{p}<0.05$; SEM $=$ Standard error of mean.

to younger tissues (Kalmbacher, 1983), consistent with previous findings by several studies (Tolera and Sundstol, 1999; Madibela et al., 2002).

The NDF and ADF contents occurred at the lowest levels in leaf blade (Table 1), similar to results reported by Schulthess et al. (1995), Tan et al. (1995), and Tang et al. (2006). However, the highest NDF and ADF contents were found in ear husk and stem rind, respectively (Table 1), inconsistent with previous findings by the abovementioned studies. These different results are possibly resulted from different selection of corn plant fractions for chemical compositional analysis.

Results of the present study showed that stem rind had the highest ADF and ADL contents while leaf blade had the lowest NDF and ADF contents (Table 1). Previously, Hay et al. (1953) indicated that corn leaf and stalk contribute a substantial $\mathrm{N}$ source to corn kernel $(60 \%$ and $26 \%$, respectively), and Crawford et al. (1982) reported that corn stalk and leaf are the main $\mathrm{N}$ sources of corn kernel. The fiber content was unevenly distributed in corn stover partly because that corn stems contain abundant structural and conducting tissues while the leaves are largely occupied by thin-walled mesophyll cells.

Our results indicate that the $\mathrm{Ca}$ and $\mathrm{P}$ contents of corn stover are mainly distributed in surface organs, similar to the distribution of mineral elements in other straw crops (Kalmbacher, 1983). This phenomenon can be attributed to plant transpiration which causes substantial evaporation of water content and leads to the deposition of minerals primarily in leaf blade and leaf sheath. Additionally, the results show that the OM content followed the order of stem rind>ear husk>stem node>stem pith>whole plant>leaf sheath $>$ tassel $>$ leaf blade. This observation is associated with the relatively high contents of ADF and lignin in stem rind and NDF in ear husk, with less NDF and ADF in $\mathrm{Ca}-$ and P-rich leaf tissues.

\section{Ruminal degradation of major nutrient components of corn stover and its morphological fractions}

The ruminal disappearance rate of corn stover is generally low due to the low protein level, low energy, and rich fiber content. In the present study, the ruminal disappearance rates of various corn stover fractions were found obviously higher at $24 \mathrm{~h}, 48 \mathrm{~h}$, and $72 \mathrm{~h}$ than at 4 to

Table 4. Ruminal disappearance rate (\%) of ADF from whole corn stover and different morphological fractions

\begin{tabular}{llcccccc}
\hline \multirow{2}{*}{ Fraction } & \multicolumn{6}{c}{ Ruminal disappearance rate of acid detergent fiber at different time points (h) } \\
\cline { 2 - 8 } & \multicolumn{1}{c}{0} & 4 & 8 & 12 & 24 & 48 & 72 \\
\hline Leaf sheath & $1.87 \pm 0.31^{\mathrm{b}}$ & $5.96 \pm 0.38^{\mathrm{e}}$ & $14.79 \pm 0.59^{\mathrm{cd}}$ & $16.67 \pm 0.87^{\mathrm{d}}$ & $29.05 \pm 0.67^{\mathrm{c}}$ & $43.25 \pm 1.49^{\mathrm{c}}$ & $51.96 \pm 2.53^{\mathrm{de}}$ \\
Leaf blade & $2.36 \pm 0.16^{\mathrm{ab}}$ & $16.97 \pm 0.71^{\mathrm{bc}}$ & $18.58 \pm 1.28^{\mathrm{b}}$ & $19.80 \pm 0.21^{\mathrm{cd}}$ & $33.57 \pm 1.26^{\mathrm{b}}$ & $60.36 \pm 2.16^{\mathrm{a}}$ & $63.68 \pm 0.83^{\mathrm{ab}}$ \\
Stem pith & $2.35 \pm 0.47^{\mathrm{ab}}$ & $18.14 \pm 0.35^{\mathrm{ab}}$ & $22.94 \pm 0.37^{\mathrm{a}}$ & $24.94 \pm 1.63$ & $49.52 \pm 0.65^{\mathrm{a}}$ & $60.35 \pm 0.77^{\mathrm{a}}$ & $66.04 \pm 0.88^{\mathrm{a}}$ \\
Stem node & $1.34 \pm 0.41^{\mathrm{b}}$ & $14.27 \pm 0.48^{\mathrm{d}}$ & $16.94 \pm 0.45^{\mathrm{bc}}$ & $19.74 \pm 0.25^{\mathrm{cd}}$ & $23.14 \pm 0.4 .3^{\mathrm{d}}$ & $46.74 \pm 1.53^{\mathrm{c}}$ & $54.03 \pm 0.83^{\mathrm{d}}$ \\
Stem rind & $1.41 \pm 0.31^{\mathrm{b}}$ & $18.74 \pm 0.16^{\mathrm{a}}$ & $21.21 \pm 0.87^{\mathrm{a}}$ & $24.76 \pm 1.21^{\mathrm{ab}}$ & $31.33 \pm 1.19^{\mathrm{bc}}$ & $43.03 \pm 1.11^{\mathrm{c}}$ & $49.24 \pm 1.30^{\mathrm{e}}$ \\
Ear husk & $3.33 \pm 0.26^{\mathrm{a}}$ & $4.79 \pm 0.14^{\mathrm{e}}$ & $14.17 \pm 0.53^{\mathrm{d}}$ & $22.37 \pm 1.00^{\mathrm{bc}}$ & $30.41 \pm 0.36^{\mathrm{bc}}$ & $57.89 \pm 1.06^{\mathrm{a}}$ & $61.10 \pm 1.41^{\mathrm{bc}}$ \\
Tassel & $3.08 \pm 0.30^{\mathrm{a}}$ & $13.69 \pm 0.68^{\mathrm{d}}$ & $16.25 \pm 0.41^{\mathrm{cd}}$ & $19.08 \pm 0.51^{\mathrm{cd}}$ & $33.75 \pm 1.84^{\mathrm{b}}$ & $53.21 \pm 0.64^{\mathrm{b}}$ & $53.23 \pm 0.84^{\mathrm{d}}$ \\
Whole plant & $2.18 \pm 0.44^{\mathrm{ab}}$ & $15.39 \pm 0.79^{\mathrm{cd}}$ & $18.97 \pm 0.42^{\mathrm{b}}$ & $26.15 \pm 0.77^{\mathrm{a}}$ & $32.87 \pm 1.60^{\mathrm{bc}}$ & $51.69 \pm 1.19^{\mathrm{b}}$ & $59.09 \pm 1.03^{\mathrm{c}}$ \\
p-value & 0.09 & $<0.001$ & $<0.001$ & $<0.001$ & $<0.001$ & $<0.001$ & $<0.001$ \\
SEM & 0.17 & 1.07 & 0.66 & 0.75 & 1.44 & 1.39 & 1.21
\end{tabular}

${ }^{\mathrm{a}-\mathrm{e}}$ Means in the same column with different letters are statistically different at $\mathrm{p}<0.05$; SEM $=$ Standard error of mean. 
Table 5. The effective degradability (ED, \%) of dry matter, neutral detergent fiber, and acid detergent fiber of whole corn stover and different morphological fractions

\begin{tabular}{lccc}
\hline Fraction & Dry matter & $\begin{array}{c}\text { Neutral } \\
\text { detergent fiber }\end{array}$ & $\begin{array}{c}\text { Acid detergent } \\
\text { fiber }\end{array}$ \\
\hline Leaf sheath & $36.40 \pm 0.70^{\mathrm{d}}$ & $34.12 \pm 0.66^{\mathrm{d}}$ & $32.21 \pm 0.64^{\mathrm{e}}$ \\
Leaf blade & $46.44 \pm 0.37^{\mathrm{a}}$ & $43.70 \pm 0.53^{\mathrm{b}}$ & $41.25 \pm 0.57^{\mathrm{b}}$ \\
Stem node & $32.73 \pm 0.40^{\mathrm{e}}$ & $34.23 \pm 0.19^{\mathrm{d}}$ & $33.45 \pm 0.34^{\mathrm{e}}$ \\
Stem pith & $45.81 \pm 0.54^{\mathrm{a}}$ & $45.69 \pm 0.18^{\mathrm{a}}$ & $45.26 \pm 0.15^{\mathrm{a}}$ \\
Stem rind & $31.95 \pm 0.44^{\mathrm{e}}$ & $32.72 \pm 0.47^{\mathrm{e}}$ & $33.55 \pm 0.79^{\mathrm{e}}$ \\
Ear husk & $42.34 \pm 0.10^{\mathrm{b}}$ & $40.68 \pm 0.17^{\mathrm{c}}$ & $38.21 \pm 0.07^{\mathrm{c}}$ \\
Tassel & $35.05 \pm 0.44^{\mathrm{d}}$ & $33.59 \pm 2.64^{\mathrm{e}}$ & $36.08 \pm 0.17^{\mathrm{e}}$ \\
Whole plant & $40.37 \pm 0.09^{\mathrm{c}}$ & $39.84 \pm 0.27^{\mathrm{c}}$ & $38.42 \pm 0.14^{\mathrm{c}}$ \\
p (ED) & $<0.001$ & $<0.001$ & $<0.001$ \\
SEM (ED) & 1.12 & 0.99 & 0.87 \\
\hline a-f Mean values in the same column followed by different letters are \\
\multicolumn{3}{c}{ statistically different at $\mathrm{p}<0.05}$. \\
ED = Effective degradability $(\%)$; SEM = Standard error of mean.
\end{tabular}

$12 \mathrm{~h}$, similar to the results reported in soybean straw by Maheri-Sis et al. (2011). Regarding the effective degradability of major nutrient contents (e.g., DM, NDF, and ADF), leaf blade, ear husk, and stem pith had significantly higher values while stem rind had the lowest values compared to other corn stover fractions. The difference between ruminal degradation rate and effective degradability of corn stover can be related to the different physical structures and chemical composition of various corn stover fractions. Previously, Hunt et al. (1992) studied the digestibility of different fractions of straw and proposed that the lower the ADL content the higher its digestibility, whereas other studies indicated that lignin content is the primary limiting factor of forage digestion (Jung and Allen, 1995).

Additionally, different physiological functions of various straw fractions are the main factor that influences their digestion and utilization. For example, plant stem mainly plays a supporting role and participates in defense against diseases and pests as well as protection from cold. Thus, stem rind contains relatively high lignin content that is difficult to be digested. On the other hand, leaves mainly conduct photosynthesis and reserve nutrient contents that are easily to be digested. These explain our observation that leaf blade, ear husk and stem pith of corn stover had relatively lower $\mathrm{ADF}$ and $\mathrm{ADL}$ contents with higher ruminal disappearance rate and effective degradability than other fractions, consistent with previous findings by Hunt et al. (1992) and Tovar-Gomez et al. (1997).

\section{CONCLUSIONS}

The chemical composition of corn stover significantly varies in different morphological fractions. Evaluation of the ruminal degradation rate and effective degradability of major nutrient contents of corn stover fractions indicates that leaf blade, ear husk, and stem pith have higher nutrient levels than other fractions of corn stover, thus may have greater nutritive value. This work is of guiding significance to livestock feeding with cost-effective nutritive corn stover fractions.

\section{ACKNOWLEDGEMENTS}

This study was supported by the National Science and Technology Support Program of China (No. 2012BAD12B05-1).

\section{REFERENCES}

Ahmed, A. and J. Y. Zhu. 2006. Cornstalk as a source of fiber and energy. In: New technologies in non-wood fiber pulping and papermaking (Ed. H. Y. Zhan, F. G. Chen, and S. Y. Fu). South China University of Technology Press, Guangzhou, pp. 1-4.

AOAC. 1990. Official method of analysis. 15th Edn., Association of Official Analytical Chemists, Washington, DC., USA., 6688.

Crandell, E. B. and J. W. Worley. 1988. Optimization of a device for separating sweet sorghum pith. American Society of Agricultural Engineers (88-6550): 12.

Crawford, T. W., V. V. Rending, and F. E. Bordabent. 1982. Source fluxes and sinks of nitrogen during early reproductive growth of maize. Plant Physiol. 70:1654-1660.

Goering, H. K. and P. J. Van Soest. 1970. Forage fibre analysis (apparatus, reagents, procedures and some applications). Agricultural Handbook 379. Agricultural Research Services, USDA, Washington, DC.

Grundas, S. and G. Skubisz. 2008. Physical properties of cereal grainand rape stem. Res. Agr. Eng. 54:80-90.

Han, Y. W. 2007. Assessment on feed criteria of dairy cattle in China. Chin. J. Feed Rev. 9:28-29.

Hay, R. E., E. B. Earley, and E. E. Deutkr. 1953. Concentration and translocation of nitrogen compounds in the corn plant (Zea mays) during grain development. Plant Physiol. 28:606-621.

Hess, J. A., A. E. Olson, and R. S. Jacobs. 2002. Wisconsin corn stover - Part 1: Chemical composition. Proceedings of TAPPI 2002 Fall Technical Conference. TAPPI Press.

Hunt, C. W., W. Kezar, and R. Vinande. 1992. Yield, chemical composition, and ruminal fermentability of corn whole plant, ear, and stover as affected by hybrid. Prod. Agric. 5:286-290.

Lee, S., T. F. Shupe, and C. Y. Hse. 2006. Mechanical and physical properties of agro-based fiberboard. Holz als Roh- und Werkstoff. 64:74-79.

Liu, L. and D. Wang. 2011. Experimental study on separating mechanism of corn straw. J. Northeast Agricultural University. 42:43-47. (in Chinese)

Jung, H. G. and M. S. Allen. 1995. Characteristics of plant cell walls affecting intake and digestibility of forages by ruminants. J. Anim. Sci. 73:2774-2790.

Karsli, M. A., and J. R. Russell. 2002. Prediction of the voluntary intake and digestibility of forage-based diets from chemical 
composition and ruminal degradation characteristics. Turk. Vet. Anim. Sci. 26:249-255.

Kalmbacher, R. S. 1983. Distribution of dry matter and chemical constituents in plant parts of four florida native grasses. J. Range Manag. 36:298-301.

Madibela, O. R., W. S. Boitumelo, C. Manthe, and I. Raditedu. 2002. Chemical composition and in vitro dry matter digestibility of local landraces of sweet sorghum in Botswana. Livest. Res. Rural Develop. 14(2). www.cipav.org.co/lrrd/ lrrd14/4/madi144.htm.

Maheri-Sis, N., B. Abdollahi-Ziveh, R. Salamatdoustnobar, A. Ahmadzadeh, A. Aghajanzadeh-Golshani, and M. Mohebbizadeh. 2011. Determining nutritive value of soybean straw for ruminants using nylon bags technique. Pakistan J. Nutr. 10:838-841.

Ørskov, E. R. and I. McDonald. 1979. The estimation of protein degradability in the rumen from incubation measurements weighted according to rate of passage. J. Agric. Sci. 92:499503.

Sannasgala, K. and M. C. N. Jayasuriya. 1987. The influence of plant fractions on the digestibility of rice straw. Biol. Waste. 20:153-156.

Schulthess, U., A. Tedla, M. A. Mohammed-Saleem, and A. N. Said. 1995. Effects of variety, altitude, and undersowing with legumes on the nutritive value of wheat straw. Exp. Agric. 31: 169-176.

Shand, W. J., E. R. Ørskov, and L. A. F. Morrice. 1988. Rumen degradation of straw 5 . Botanical fractions and degradability of different varieties of oat and wheat straws. Anim. Prod. 47: 387-392.

Tan, Z. L., H. P. Chen, L. H. He, R. J. Fang, and T. X. Xing. 1995. Variation in the nutritional characteristics of wheat straw. Anim. Feed Sci. Technol. 53:337-344.
Tang, S. X., Z. L. Tang, C. S. Zhou, H. L. Jiang, Y. M. Jiang, and L. X. Sheng. 2006. A comparison of in vitro fermentation characteristics of different botanical fractions of mature maize stover. J. Anim. Feed Sci. 15:505-515.

Tolera, A. and F. Sundstol. 1999. Morphological fractions of maize stover harvested at different stages of grain maturity and nutritive value of different fractions of the stover. Anim. Feed Sci. Technol. 81:1-16.

Tovar-Gomez, M. R., J. C. Emile, B. Michalet-Doreau, and Y. Barriere. 1997. In situ degradation kinetics of maize hybrid stalks. Anim. Feed Sci. Technol. 68:77-88.

Vadiveloo, J. 2000. Nutritional properties of the leaf and stem of rice straw. Anim. Feed Sci. Technol. 83:57-65.

Van Soest, P. J., J. B. Robertson, and B. A. Lewis. 1991. Methods for dietary neutral detergent fiber and non starch polysaccharides in relation to animal nutrition. J. Dairy Sci. 74:3583-3597.

Wang, H. F., Y. M. Wu, J. X. Liu, and Q. Qian. 2006. Morphological fractions, chemical compositions and in vitro gas production of rice straw from wild and brittle culm1 variety harvested at different growth stages. Anim. Feed Sci. Technol. 129:159-171

Zeng, X., Y. Ma, and L. Ma. 2007. Utilization of straw in biomass energy in China. Renew. Sustain. Energy Rev. 11:976-987.

Zhou, X., L. Tan, W. Zhang, C. L. Lv, F. Zheng, R. Zhang, G. B. Du, B. J. Tang, and X. Y. Liu. 2011. Enzymatic hydrolysis lignin derived from corn stover as an intrinsic binder for biocomposites manufacture: Effect of fiber moisture content and pressing temperature on boards' properties. BioResour. 6:253264. 